\title{
Slump test: laboratory and numerical simulation-based approach for consistency of mill tailings paste
}

\author{
S. K. Behera ${ }^{1, *}$, Prashant ${ }^{1}$, C. N. Ghosh ${ }^{1}$, D. P. Mishra ${ }^{2}$, P. K. Mandal ${ }^{1}$, \\ Aniket Verma ${ }^{1}$, Sumeet Mohanty ${ }^{3}$, Kanhaiya Mishra ${ }^{1}$ and P. K. Singh ${ }^{1}$ \\ ${ }^{1}$ CSIR-Central Institute of Mining and Fuel Research, Dhanbad 826015 , India \\ ${ }^{2}$ Indian Institute of Technology (Indian School of Mines), Dhanbad 826004 , India \\ ${ }^{3}$ Birla Institute of Technology and Science, Hyderabad 500 078, India
}

Solid-to-water proportion decides the effectiveness of paste backfill in terms of transportation characteristics during mine backfilling. This article highlights various laboratory tests conducted to determine the optimum solid-to-water ratio. Also, numerical simulation was carried out using computational fluid dynamics technique (ANSYS FLUENT) to understand the slump lifting process and variation in volume of the paste with time. The optimum slump and spread for lead-zinc mill tailings paste were in the range 190 $200 \mathrm{~mm}$ and $330-340 \mathrm{~mm}$ respectively. The optimum water content in the paste fill for this study was found to be $23 \mathrm{wt} \%$. Results show that the solid percentage is inversely related with slump and spread. Also, an optimum slump lifting speed needs to be maintained for accurate values of slump and spread.

Keywords: Computational fluid dynamics modelling, mill tailings, paste fill, slump test.

IN India the average metal content in majority of the lead-zinc ores approximately accounts for less than $5 \%$ (ref. 1). Beneficiation of ore includes a continuous system of crushing, grinding and chemical treatment which separates valuable economic mineral from the ore. In this process, the leftover fraction of material is waste and uneconomical. This leftover material is known as tailings. Surface diposal of such waste material is not the best method due to scarcity of land and adverse environmental effects $^{2}$. Mill tailings are being utilized as back-fill material for filling stopes throughout the world ${ }^{3-8}$.

Conventional cemented tailings disposed in underground stopes are of lower concentration compared to modern cemented tailings of higher concentration, which is termed as paste. Gao ${ }^{9}$ highlighted that the low-concentration cemented slurry behaves like a Newtonian fluid. In this type of material segregation occurs sometimes, which results in the separation of larger particles from the smaller ones. Low-concentration back filling requires

\footnotetext{
*For correspondence. (e-mail: skbcimfr@yahoo.com)
}

higher amount of water; thus a new way of back filling is required to eliminate higher percentage of water utilization $^{10}$. Paste-fill technology requires less water compared to conventional hydralic filling. Typically paste fill is produced by dewatering the tailings, adding suitable percentage of cement and water. Flowability of paste fill is dependent on the yield stress and viscosity of the paste material, and yield stress of the material is related to slump of the paste. Slump is dependent on water content/solid percentage, density and slumping speed, etc. of the paste 9 . The slump test is extensively used by civil engineers to estimate the 'workability or consistency' of fresh concrete ${ }^{11,12}$. The term arises from the need to know whether fresh concrete will flow to its final position: if too stiff, the mixture will not flow into tight corners of the structures to be constructed; conversely, if the concrete is too runny, water content is in excess and the ability of concrete to flow is increased, but the strength of the final hardened concrete is reduced. Therefore, it is necessary to maintain a balance between flow properties $^{13}$. Similarly, during paste backfilling, trasportaion of the paste is one of the key elements; it is related to flowability of paste backfill. An optimum solid proportion within the paste mix facilitates bulk disposal of waste material with optimum energy consumption. Mill tailings paste with high water content or low consistency is easily flowable, but may not give the required strength $^{14,15}$. Thus it is necessary to determine the optimum water percentage to be maintained in the paste mix. Slump test provides a quick and onsite tool for maintaining optimum solid proportion where sophisticated instruments are not available.

\section{Physical properties of mill tailings}

In the present study for preparing paste fill, mill tailings were used as the basic raw material. Lead-zinc mill tailings samples were collected from a lead-zinc-producing mine in Rajasthan, India (Figure 1). The bulk density $(\rho)$ of the samples was calculated and specific gravity $(G)$ 


\section{RESEARCH ARTICLES}

was determined using a water pycnometer according to IS: 2386 (Part III). The particle size distribution of leadzinc mill tailings and fly ash were determined with a particle size analyser (Malvern Mastersizer-3000) which works on wet dispersion method using laser diffraction technique.

Physical properties reveal the specific gravity of mill tailings to be 2.91 (Table 1), and particle size of leadzinc mill tailings varies in the range $0.1-420$ (Figure 2).

In the case of mill tailings since coefficient of uniformity, $C_{\mathrm{u}}>6$ and coefficient of curvature, $C_{\mathrm{c}}<1$, it is concluded that they are poorly graded according to the standard for classification and gradation of soils, viz. ASTM D-2487.

\section{Slump test experiments}

\section{Paste preparation}

Ordinary Portland Cement (OPC) was used as a binder for preparing the paste fill mix using a laboratory mixer. Various mixes were designed to determine the optimum water content of the paste fill. Based on the mix design specific percentage of water was added to the tailing samples and paste fill was prepared. Initially, mill tailings were dry mixed with OPC (OPC grade 43) conforming to
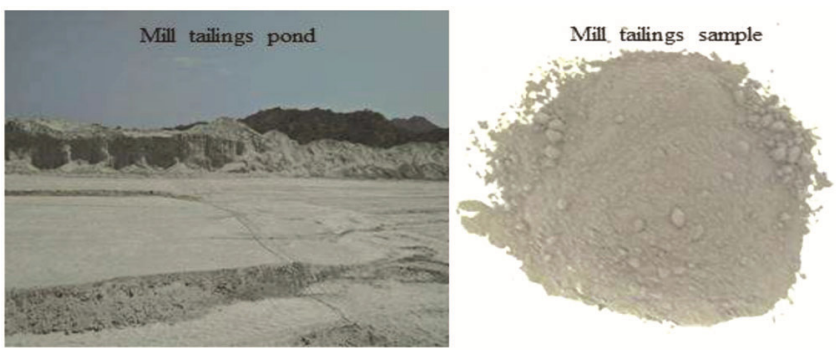

Figure 1. Mill tailings storage pond and sample.

Table 1. Physical characterization of mill tailings and fly ash

\begin{tabular}{lc}
\hline Parameters & Mill tailings \\
\hline Colour & Grey \\
Specific gravity $(G)$ & 2.91 \\
Bulk density $\left(\rho ; \mathrm{g} / \mathrm{cm}^{3}\right)$ & 1.49 \\
& \\
Particle size distribution & \\
$D(4,3)(\mu \mathrm{m})$ & 39.538 \\
$D(3,2)(\mu \mathrm{m})$ & 9.972 \\
$D_{90}(\mu \mathrm{m})$ & 89.13 \\
$D_{50}(\mu \mathrm{m})$ & 29.92 \\
$D_{10}(\mu \mathrm{m})$ & 4.75 \\
$D_{30}(\mu \mathrm{m})$ & 14.48 \\
$D_{60}(\mu \mathrm{m})$ & 50.73 \\
Coefficient of uniformity $\left(C_{\mathrm{u}}\right)^{*}$ & 10.68 \\
Coefficient of curvature $\left(C_{\mathrm{c}}\right)^{*}$ & 0.87 \\
Specific surface area $\left(\mathrm{m}^{2} / \mathrm{kg}\right)$ & 481.4 \\
\hline
\end{tabular}

$*\left(C_{\mathrm{u}}\right)=D_{60} / D_{10} ;\left(C_{\mathrm{c}}\right)=\left(D_{30} \times D_{30}\right) /\left(D_{60} \times D_{10}\right)$.
Indian standard 8112 (1989) (ref. 16) in a mixer for about 3 min. After complete dry mixing water was added and again mixed properly for about $15 \mathrm{~min}$. Several compositions of paste material were prepared in the laboratory.

\section{Slump test}

Usually for slump test a frustum of cone is used, which is called slump cone ${ }^{17,18}$. Slump is the difference in height between the slump cone and the slumped material

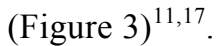

This is the most common method applied to determine the consistency or flow ability of concrete or paste material. According to ASTM C 143, standard conical frustum of $30 \mathrm{~cm}$ height with top and bottom diameters of 10 and $20 \mathrm{~cm}$ respectively, and metal thickness of $1.60 \mathrm{~mm}$ was used as the apparatus. Prepared mill tailings paste was poured into the slump cone. The top surface was flattened with a spatula. The slump cone was lifted smoothly till the slump material subsided. The surface of the slumped material is not uniform; so slump was measured at five different locations and mean of these values was considered as the final slump value (Figure 4). The diameter of the slumped material was measured in two orthogonal directions; this is known as spread. The mean of the two measured values was considered as the final spread of the material. Density $\left(\mathrm{kg} / \mathrm{m}^{3}\right)$ of the paste material was also determined in the laboratory simultaneously, so as to eliminate errors due to time-lag.

\section{Results and discussion of slump test}

Table 2 presents the results of various slump tests. The slump values were observed to decrease with increase in solid percentage $(75 \%-80 \%$ by weight). Moreover, similar kind of trend was observed with spread. It is noteworthy to mention here that pulp or paste density decreased with increase in water content. Reduction in density is a natural phenomenon, as addition of more water makes the paste backfill thin. The drastic reduction in paste density may be due to drastic variation of specific gravity of mill tailings (2.93) compared to water (1).

Clayton et ll $^{17}$ suggested paste with a slump of 190 $200 \mathrm{~mm}$ to be workable. Figure $5 a$ and $b$ shows the effect of solid percentage on slump and spread for $8 \mathrm{wt} \%$ OPC compositions.

\section{Numerical simulation of slump test}

\section{Brief background}

Haiqiang et al. ${ }^{19}$ reported that the paste can be considered as a Bingham fluid. For the present study computational fluid dynamics (CFD; ANSYS FLUENT Release 14.5) has been used. It provides comprehensive modelling 


\begin{tabular}{lcccccc} 
Table 2. & Slump test results \\
\hline $\begin{array}{l}\text { Mix } \\
\text { sample }\end{array}$ & $\begin{array}{c}\text { Tailings by } \\
\text { weight (\%) }\end{array}$ & $\begin{array}{c}\text { Ordinary Portland cement } \\
\text { by cement weight (\%) }\end{array}$ & $\begin{array}{c}\text { Solid-to-water ratio } \\
\text { (by weight) }\end{array}$ & $\begin{array}{c}\text { Slump } \\
(\mathrm{mm})\end{array}$ & $\begin{array}{c}\text { Spread } \\
(\mathrm{mm})\end{array}$ & $\begin{array}{c}\text { Density } \\
\left(\mathrm{kg} / \mathrm{m}^{3}\right)\end{array}$ \\
\hline$C_{8 \mathrm{a}}$ & 92 & 8 & $80: 20$ & 151 & 311 & 2340 \\
$C_{8 \mathrm{~b}}$ & 92 & 8 & $79: 21$ & 166 & 320 & 2280 \\
$C_{8 \mathrm{c}}$ & 92 & 8 & $78: 22$ & 184 & 332 & 2200 \\
$C_{8 \mathrm{~d}}$ & 92 & 8 & $77: 23$ & 195 & 340 & 2130 \\
$C_{8 \mathrm{e}}$ & 92 & 8 & $76: 24$ & 210 & 346 & 2020 \\
$C_{8 \mathrm{f}}$ & 92 & 8 & $75: 25$ & 250 & 355 & 1890 \\
\hline
\end{tabular}

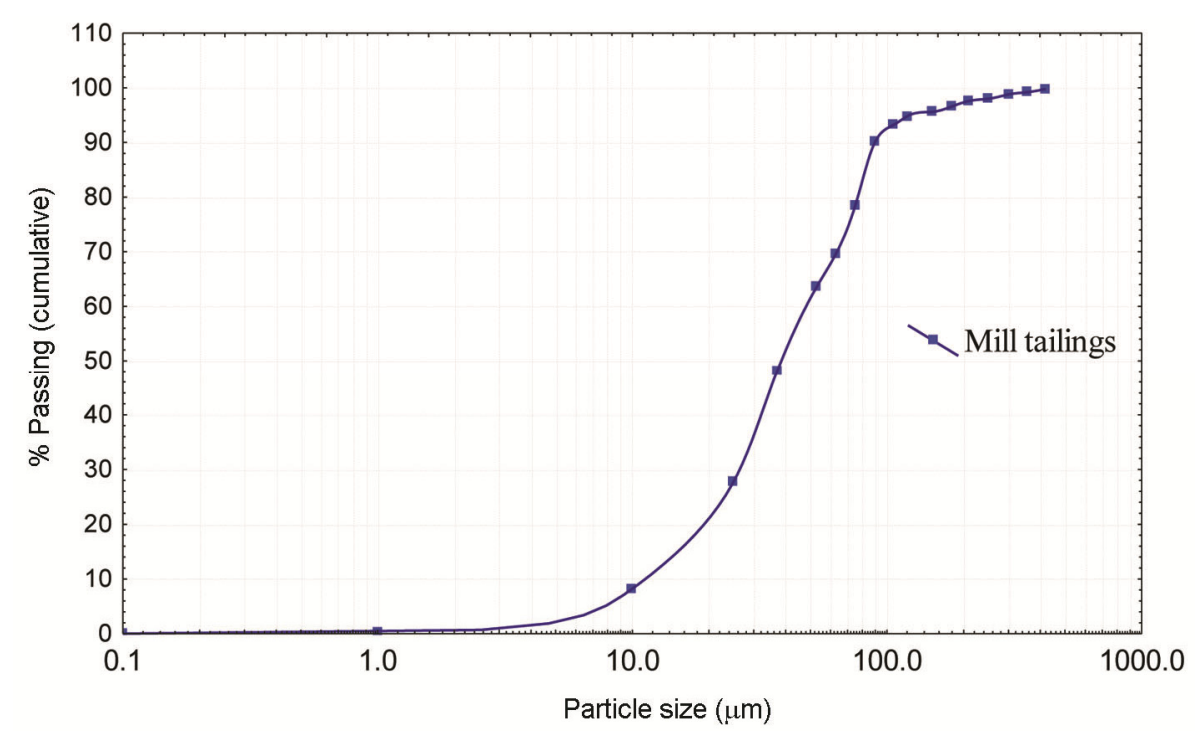

Figure 2. Particle size distribution curve for mill tailings.

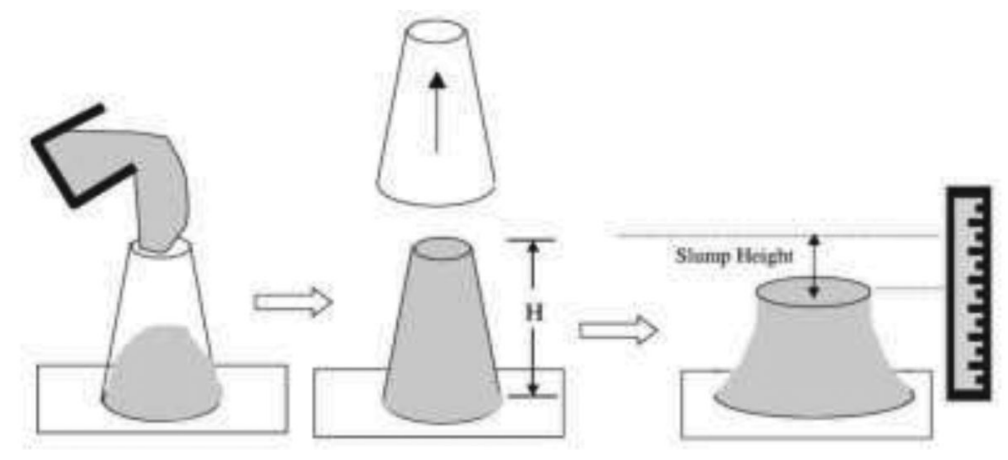

Figure 3. Slump cone test ${ }^{11}$.

capabilities for a wide range of incompressible and compressible, laminar and turbulent fluid-flow problems. Steady-state or transient analyses can also be performed.

\section{Model geometry and input parameters}

For slump cone simulation, a 2D geometry can be used. The domain includes three regions: paste region, mould region and air region. Figure 6 shows the dimensions of each region and boundary conditions.
To obtain better accuracy in the results, comparatively finer mesh is generated near the boundaries of slump cone and air interface. Figure 7 shows the generated mesh.

The slump cone simulation was conducted with six paste samples. Table 3 summarizes the properties used for simulation. The simulation includes the following steps: (i) Developing geometry of the slump cone and specifying boundary conditions, (ii) Conversion of geometry into a surface, (iii) Mesh generation and refinement, (iv) in 


\section{RESEARCH ARTICLES}

the set-up menu of ANSYS FLUENT boundary conditions, material properties, ambient conditions, etc. are specified.

To simulate the slump cone lifting process, three different lifting velocities were considered in the numerical simulation $(0.005,0.01$ and $0.05 \mathrm{~m} / \mathrm{s})$. The iteration was stopped when the slumping and spreading speeds reached below $0.1 \mathrm{~mm} / \mathrm{s}$.
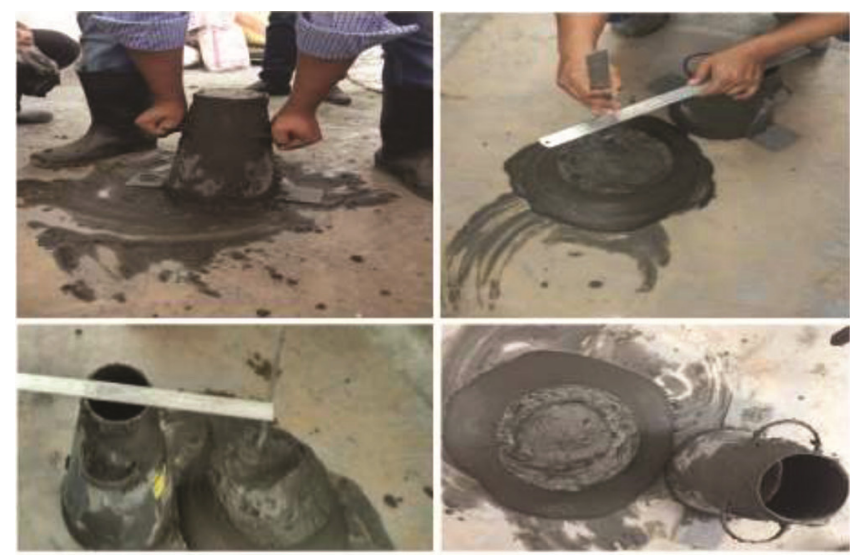

Figure 4. Photographs of various slump tests.
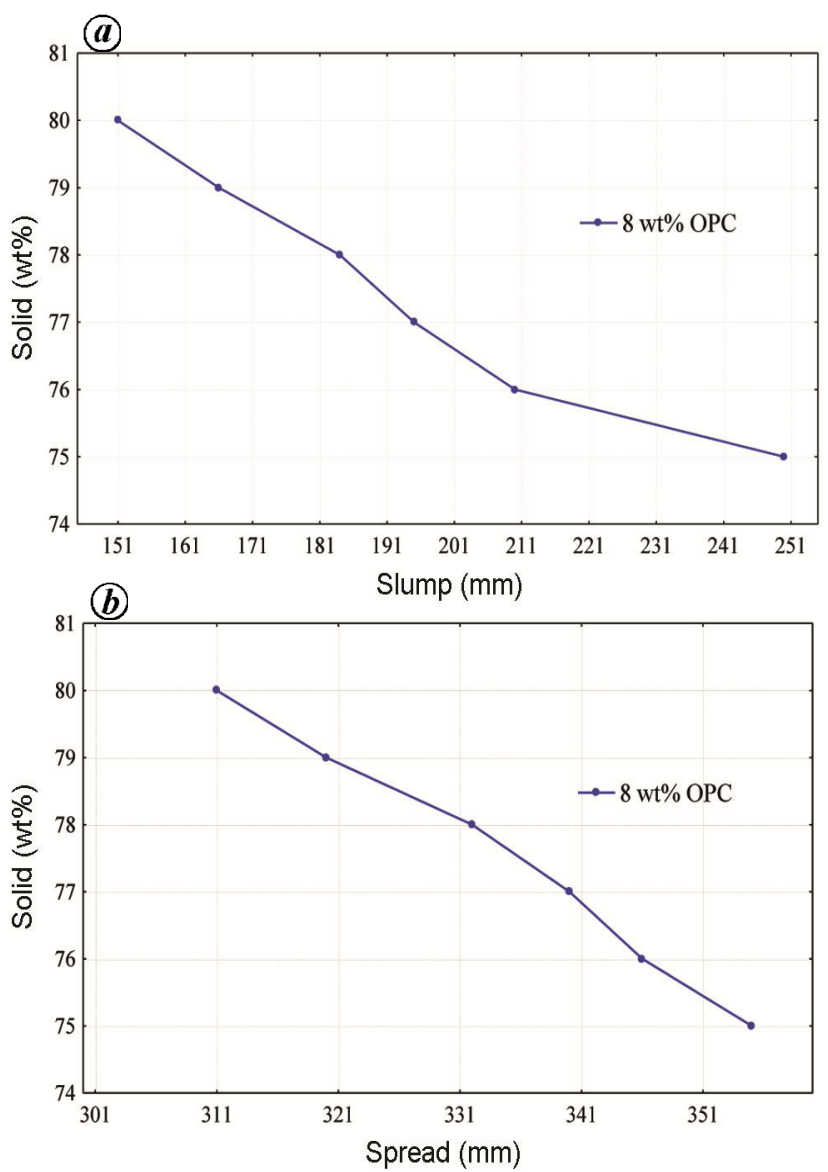

Figure 5. Variation of (a) slump and (b) spread with solid percentage.

\section{Results and discussion of numerical simulation}

Figure $8 a-f$ shows the simulation results. It explains the change in volume of paste material and spread with time. Slump lifting speed affects the slump and spread. Thus, it is necessary to have a uniform slump lifting speed.

Figure 9 summarizes spread versus slumping time for different solid percentages $(w t \%)$ of the paste. It shows that with increase in solid content the spread decreases, and it takes comparatively less time to finally reach a constant value.

Figure 10 explains the effect of slump cone lifting velocity on the spread based on numerical simulation results. It is observed that a faster cone lifting process results in a higher value of the spread, which is a natural fact. In contrast, a slower lifting process results in a lower spread value. Thus, a optimum lifting velocity needs to be maintained during the slump test.

\section{Comparison between laboratory and numerical simulation results}

Table 4 represents the basic statistical analysis for both laboratory and numerical simulation methods.

The analysis shows that coefficient of variation $(\mathrm{CV})$ is slightly higher for the experimental method compared to the numerical simulation; but it can be concluded that for

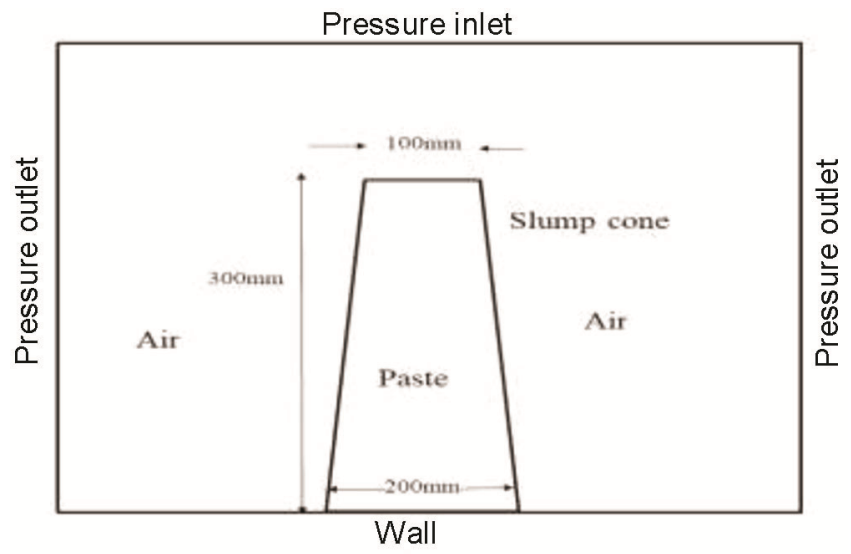

Figure 6. Geometry and boundary conditions of slump cone test.

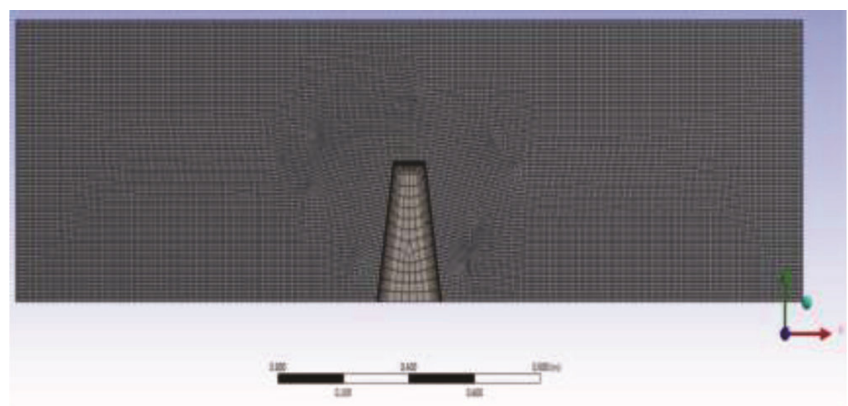

Figure 7. Generated mesh of slump cone simulation. 
RESEARCH ARTICLES
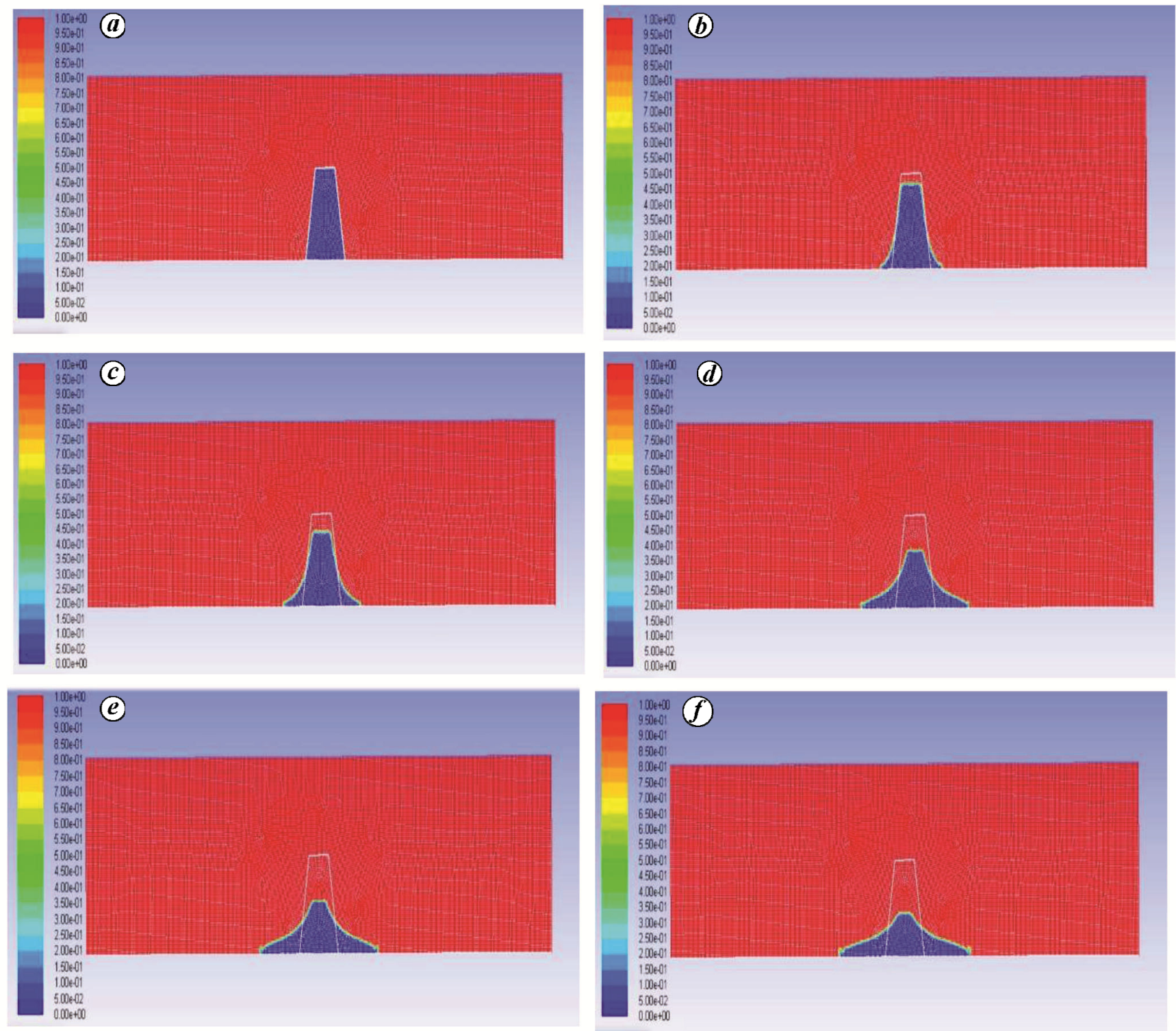

Figure 8. Contours of volume fraction at different slumping times. Time (a) $0 \mathrm{~s},(\boldsymbol{b}) 2.1 \mathrm{~s},(\boldsymbol{c}) 2.3 \mathrm{~s},(\boldsymbol{d}) 2.6 \mathrm{~s},(\boldsymbol{e}) 3.6 \mathrm{~s}$ and $(\boldsymbol{f}) 11 \mathrm{~s}$

Table 3. Input parameters used in numerical simulation

\begin{tabular}{lccc}
\hline $\begin{array}{c}\text { Sample } \\
\text { stress (Pa) }\end{array}$ & $\begin{array}{c}\text { Density } \\
\left(\mathrm{kg} / \mathrm{m}^{3}\right)\end{array}$ & $\begin{array}{c}\text { Plastic } \\
\text { viscosity (Pa S) }\end{array}$ \\
\hline $\mathrm{C}_{8 \mathrm{a}}$ & 285 & 2340 & 3.2 \\
$\mathrm{C}_{8 \mathrm{~b}}$ & 278 & 2280 & 2.9 \\
$\mathrm{C}_{8 \mathrm{c}}$ & 273 & 2200 & 2.6 \\
$\mathrm{C}_{8 \mathrm{~d}}$ & 260 & 2130 & 2.5 \\
$\mathrm{C}_{8 \mathrm{e}}$ & 255 & 2020 & 2.2 \\
$\mathrm{C}_{8 \mathrm{f}}$ & 246 & 1890 & 1.9 \\
\hline
\end{tabular}

Table 4. Covariance measurement

\begin{tabular}{lllc}
\hline Method & Mean & SD & CV (\%) \\
\hline A (laboratory) & 334 & 16.431 & 4.92 \\
B (simulation) & 332.33 & 15.92 & 4.79 \\
\hline
\end{tabular}

a given scenario numerical modelling gives more accurate results than the laboratory experiment. The latter may involve some human error, so that it shows higher coefficient of variation. The correlation coefficient between both methods was found to be 0.992, while the value of $R^{2}$ and adjusted $R^{2}$ was 0.9832 and 0.979 respectively, which shows good fitting of linear model between laboratory and numerical simulation results (Figure 11).

ANOVA test for slump (laboratory): Table 5 shows the ANOVA results for the slump values obtained through laboratory experiment. The ANOVA tested the adequacy of fit for the mixture models. The model selected for the response variable was the linear mixture model, as a $P$-value is 0.001 which is less than the significance level 0.05 was obtained. The value of $R^{2}$ and adjusted $R^{2}$ was 
Table 5. ANOVA test for slump (laboratory)

\begin{tabular}{lccccc}
\hline Model & Sum of squares & $\mathrm{d} f$ & Mean square & $F$ & Signature \\
\hline Regression & 1337.657 & 1 & 1337.657 & 433.500 & 0.00 \\
Residual & 22.639 & 4 & 5.660 & & \\
Total & 1350.000 & 5 & & & \\
$R^{2}=0.991$, Adj $R^{2}=0.989$ & & & & & \\
\hline
\end{tabular}

Table 6. ANOVA test for slump (numerical simulation)

\begin{tabular}{lccccc}
\hline Model & Sum of squares & $\mathrm{d} f$ & Mean square & $F$ & Signature \\
\hline Regression & 1218.057 & 1 & 1218.057 & 98.876 & 0.001 \\
Residual & 49.276 & 4 & 12.319 & & \\
Total & 1267.333 & 5 & & \\
$R^{2}=0.961$, Adj $R^{2}=0.951$ & & & & & \\
\hline
\end{tabular}

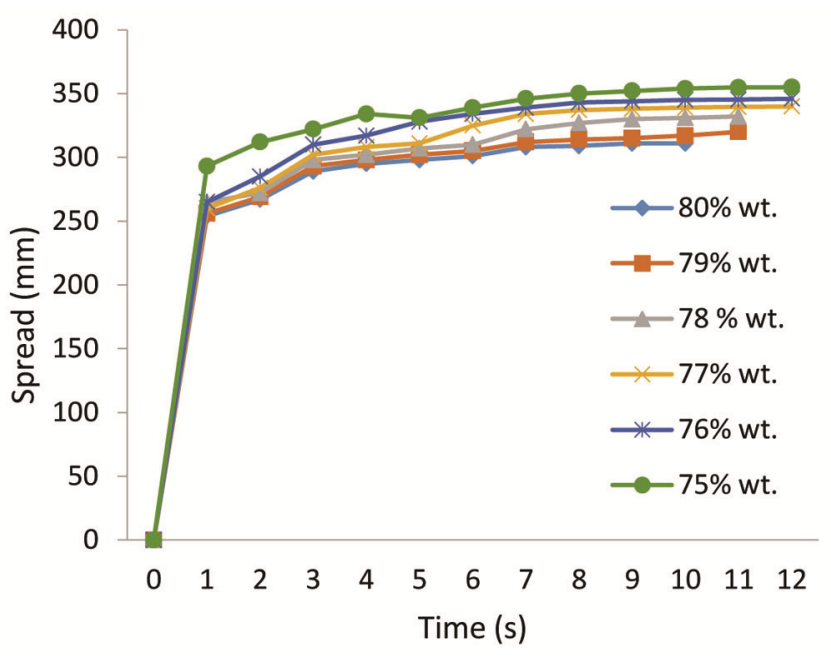

Figure 9. Change in spread with time simulation results for different concentrations (by weight) of paste.

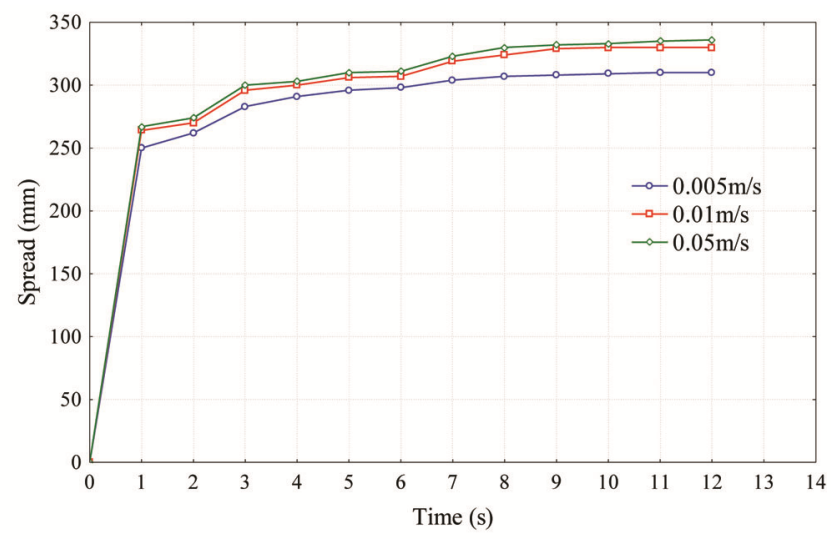

Figure 10. Change in spread with slumping speed simulation results.

found to be 0.991 and 0.989 respectively, which shows good fitting of linear trend equation.

ANOVA test for slump (numerical analysis): Table 6 shows the ANOVA results for the slump values obtained

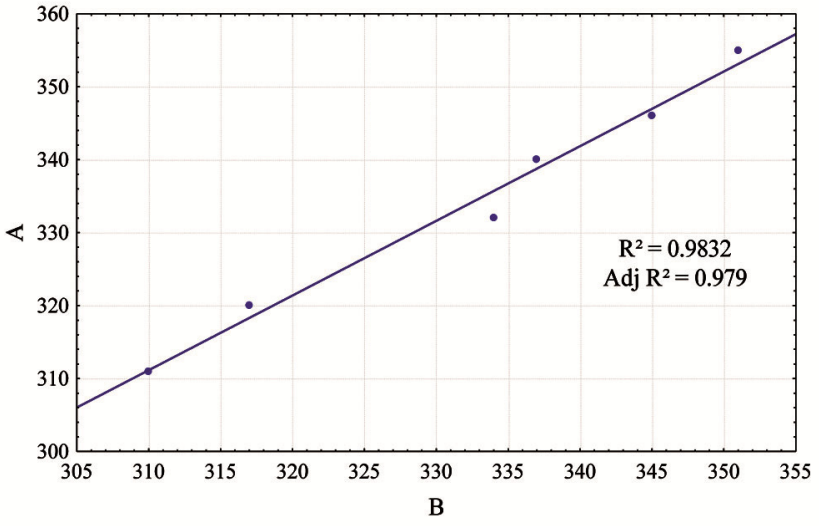

Figure 11. Laboratory versus numerical simulation results.

through numerical simulation. The ANOVA tested the adequacy of fit for the mixture models. The model selected for the response variable was the linear mixture model, as a $P$-value is 0.001 which is less than the significance level 0.05 was obtained. The value of $R^{2}$ and adjusted $R^{2}$ for slump test was 0.961 and 0.951 respectively; these were slightly less than the regression values obtained for slump test for laboratory experiment. Hence, it can be concluded that slump values obtained through laboratory experiment can be better predicted through linear trend equation compared to numerical analysis.

\section{Conclusion}

The results of slump test show the optimum slump value for mill tailings (lead-zinc) paste to be in the range 190$200 \mathrm{~mm}$. The spread needs to be in the order of 330 $340 \mathrm{~mm}$ for this particular case study considering $8 \mathrm{wt} \%$ OPC in the paste mix. Based on the slump results, optimum water content in the paste fill was found to be $23 \%$ by weight. Due to its simplicity and ease of operation, the slump test can be used in the field to determine consistency of paste fill. 
The various factors affecting slump are solid percentage, and slump cone lifting speed. Results show that with an increase in solid percentage the slump decreases, a decrease in the slump shows a thick paste fill which may have higher yield stress and viscosity. The numerical simulation results help us clearly understand the slumping process. They also explain the change in spread with time. It is found that the slumping time for the present paste fills is $11-12 \mathrm{~s}$. Also, numerical simulation with varying slump lifting speeds shows that the spread is directly related to the cone lifting speed. Thus an optimum slump cone lifting speed is necessary to have an accurate slump.

1. http://ibm.nic.in/writereaddata/files/08092017094123Leadzinc2015 (Final).pdf (accessed on 21 December 2017).

2. Edraki, M., Baumgartl, T., Manlapig, E., Bradshaw, D., Franks, D. M. and Moran, C. J., Designing mine tailings for better environmental, social and economic outcomes: a review of alternative approaches. J. Clean. Prod., 2014, 84(1), 411-420; doi:10.1016/j. jclepro.2014.04.079.

3. Belem, T. and Benzaazoua, M., Design and application of underground mine paste backfill technology. Geotech. Geol. Eng., 2008, 26(2), 147-174.

4. Deb, D., Sreenivas, T., Dey, G. K. and Panchal, S., Paste backfill technology: essential characteristics and assessment of its application for mill rejects of uranium ores. Trans. Indian Inst. Metals, 2017, 70(2), 487-495.

5. Ercikdi, B., Cihangir, F., Kesimal, A. and Deveci, H., Practical importance of tailings for cemented paste backfill. In Paste Tailings Management (eds Yilmaz, E. and Fall, M.), Springer, Cham, Switzerland, 2017, pp. 7-32.

6. Helsinki, M., Fourie, A., Fahey, M. and Ismail, M., Assessment of the self-desiccation process in cemented mine back fills. Can. Geotech. J., 2007, 44, 1148-1156.

7. Jewell, R. J., Fourie, A. B. and Lord, E. R., Paste and Thickened Tailings - A Guide, Australian Centre of Geomechanics, Perth, Australia, 2002
8. Potvin, Y., Thomas, E. H. and Fourie, A. B., Handbook on Mine Fill, ACG Publication, Perth, Australia, 2005.

9. Gao, J., Investigation of the flume test and mini-slump test for thickened tailings disposal. Ph D thesis, Princeton University, NJ, USA, 1991.

10. Yılmaz, E., Kesimal, A., Erçıktı, B. and Alp, İ., Determination of the optimum cement content for paste backfill samples. In 18th International Mining Congress and Exhibition of Turkey-IMCET, Antalya, 2003, pp. 119-125.

11. Boger, D. V., Rheology and the resource industries. Chem. Eng. Sci., 2009, 64, 4525-4536.

12. Pashias, N., Boger, D. V., Summers, J. and Glenister, D. J., A fifty cent rheometer for yield stress measurement. J. Rheol., 1996, 40, 1179-1189.

13. Bingham, E. C., Fluidity and Plasticity, McGraw-Hill Book Company, Inc, New York, USA, 1922.

14. Robinsky, E. I., Thickened discharge - a new approach to tailings disposal. CIM Bull., 1975, 68, 47-53.

15. Robinsky, E. I., Tailings disposal by the thickened discharge method for improved economy and environmental control. In Tailings Disposal Today, Proceedings of the Second International Tailings Symposium, Denver, Colorado, USA, 1978, pp. 75-92.

16. BIS, IS 8112: 43 grade ordinary Portland cement - specification, Bureau of Indian Standards, New Delhi, 1989.

17. Clayton, S., Grice, T. G. and Boger, D. V., Analysis of the slump test for on-site yield stress measurement of mineral suspensions. Int. J. Miner. Proc., 2003, 70, 3-21.

18. Roussel, N. S. and Leroy, R., From mini cone test to Abrams cone test: measurement of cement based materials yield stress using slump tests. Cem. Concr. Res., 2005, 35, 817-822.

19. Haiqiang, J., Fall, M. and Cui, L., Yield stress of cemented paste backfill in sub-zero environments: experimental results. Miner. Eng., 2016, 92, 141-150.

ACKNOWLEDGEMENTS. We thank the management of Hindustan Zinc Limited (HZL), Udaipur, Rajasthan for financial support to conduct this study.

Received 7 June 2018; revised accepted 12 March 2019

doi: $10.18520 / \mathrm{cs} / \mathrm{v} 117 / \mathrm{i} 2 / 235-241$ 